\title{
FACTORS ASSOCIATED WITH LETHAL OUTCOME IN PATIENTS WITH SEVERE FORM OF INFLUENZA
}

\section{Marija Cvetanovska', Zvonko Milenkovik ${ }^{1}$, Valerija Kirova Uroshevik ${ }^{1}$, Ilir Demiri' ${ }^{1}$, Vlatko Cvetanovski²}

${ }^{1}$ Clinic of Infectious Diseases and Febrile Conditions, Clinical Center, Skopje, R. Macedonia

${ }^{2}$ General Hospital Remedika, Skopje, R. Macedonia

Corresponding Author: Marija Cvetanovska, Blvd. AVNOJ 18-1/4, Skopje, R. Macedonia; tel: 022462106; e-mail:mcvetanovska2001@yohoo.com

\begin{abstract}
Introduction: Clinical manifestations of influenza range from relatively mild and self-limiting respiratory infections to severe clinical manifestations with significant morbidity and mortality. The awareness of predictive indicators for the lethal outcome of influenza is of particular significance in making timely and exact decision for adequate treatment. The aim of this study was to identify the factors in patients with a severe form of influenza, resulting in lethal outcome.

Materials and methods: The investigation was a prospective group comparison conducted at the University Clinic for Infectious Diseases in Skopje, R. Macedonia in the period from January 01, 2012 to January 01, 2015. The study included adult patients with a severe form of influenza who were further categorized into a group of either survived patients or a group of deceased patients. Demographic, clinical and biochemical data were noted in all patients included in the study on admission. The variables of the univariate analysis that showed a significant difference in terms of the outcome were used for creating multivariate logistic and regression analysis of the outcome as dependent factors. The independent predictors for lethal outcome in severe cases of influenza were identified by using logistic regression.

Results: The study included 87 patients with a severe form of clinical and laboratory confirmed influenza. The patients were divided in two groups: survived $(n=75)$ and deceased $(n=75)$. The overall mortality was $13.79 \%$. Multivariate analysis conducted on admission to hospital identified cardiovascular comorbid diseases $(p=0.014)$, urea values higher than $8.3 \mathrm{U} / \mathrm{L}(\mathrm{p}=0.045)$ and SAPS score $(p=0.048)$ as independent predictors of the outcome in patients with severe form of influenza. Influenza patients with cardiovascular diseases had 2.024 times greater risk of death from influenza in comparison to the patients having influenza without history of such a disease (OR $=2.02495 \%$ CI 1.842-17.337). Patients with serum urea values higher than $8.3 \mathrm{U} / \mathrm{L}$ had 1.89 times higher chance of death compared to patients with normal values (OR $=1.8995 \%$ CI 1.091-11.432). The increase of the SAPS score in one point increased the chance of death in patients with influenza by $1.2 \%$ (OR = 1.12 95\% CI 1.01-2.976). The ROC analysis indicated that cardiovascular diseases, increased urea values and SAPS score in combination act as a good prognostic model for the fatal outcome. The global authenticity of this predictive model to foresee lethal outcome amounts to $80 \%$, sensitivity being $82 \%$, and specificity $70 \%$.

Conclusion: Cardiovascular diseases, increased values of urea over $8.3 \mathrm{mmol} / \mathrm{l}$ and SAPS score are independent predictive indicators for lethal outcome in severe influenza. Early identification of the outcome predictors in patients with severe influenza will allow implementation of adequate medical treatment and will contribute to decreasing of mortality in patients with severe form of influenza.
\end{abstract}




\section{Introduction}

Clinical manifestations of influenza range from relatively mild and self-limiting respiretory infections to severe clinical manifestations with significant morbidity and mortality [1]. During seasonal epidemics from 3 to 5 million severe cases and about 250.000-500.000 lethal cases are registered worldwide [2]. Until now there has not been a laboratory test which has served as a potential marker for identification of patients with a high risk of developing severe clinical forms of influenza and lethal outcome $[3,4]$. It is known that patients with different comorbid conditions such as diabetes mellitus, chronic cardiovascular and pulmonary diseases, immunosuppressive conditions, adult patients and other conditions are at higher risk of developing severe clinical course of the disease and lethal outcome [5]. Although the influenza virus is primarily a respiratory pathogen, the severe clinical forms of the disease are manifested as systemic infections with multisystem organ affection, and even $10-30 \%$ of the diseased need intensive treatment $[6,7]$. Pneumonia, delayed antiviral treatment, severe hypoxemia and multisystem organ failure are most commonly referred as leading risk factors for lethal outcome [8]. The largest number of studies has evaluated isolated risk factors leading to lethal outcome and only a few of them have been focused on the complete palette of predictors for development of a severe form of the disease and lethal outcome [9-12]. From the clinical practice point of view, the awareness/recognition of the risk factors and predicttors for lethal outcome of influenza is of particular importance in bringing timely and exact decision for hospitalization, treatment or undertaking special measures for intensive monitorring of these patients.

Severe influenza is defined by signs for respiratory weakness (dyspnea, tachypnea, hypoxia, cyanosis) that is arterial $\mathrm{PaO} 2<70 \mathrm{mmHg}$ $(<9.0 \mathrm{kPa})$ and/or need of mechanical ventilation or signs of ARDS ( $\mathrm{PaO} 2 / \mathrm{FiO} 2 \leq 200)$, intensive care, severe complications, exacerbation of the existing chronic disease.

The aim of this study was to identify the risk factors that lead to lethal outcome in patients with severe form of influenza.

\section{Materials and methods}

The study was designed in accordance with the ethics principles of the Declaration of
Helsinki for patients and their rights, and was approved by the Ethics Committee of the Medical Faculty of Ss. Cyril and Methodius University in Skopje.

The study was clinical, prospective, group comparison and it was performed at the Clinic for Infectious Diseases and Febrile Conditions in a three-year-period (01.01.2012-01.01.2015).

A total of 87 patients with severe forms of clinically and laboratory confirmed influenza were analyzed. The patients were divided into two groups:

Group 1 contained 75 patients who survived and

Group 2 contained 12 patients who had lethal outcome

Criteria for inclusion in the study:

All patients with clinical and laboratory confirmed severe form of influenza.

- Age $\geq 16$ years

\section{Criteria for exclusion of the study:}

- Patients were excluded if they died in the first 24 hours of their inclusion in the study. Those that did not receive approval for inclusion

On admission of patients, the following parameters were noted: demographic characterristics, comorbidities, clinical signs of the disease and laboratory-biochemical characteristics.

For determining the presence of the influenza virus nasopharyngeal smear was used. In the Laboratory of virology and molecular diagnosis at the Institute for Public Health from the previously isolated RNA (ribonucleic acid) real time RT-PCR (reverse transcriptase/ion-polymerase chain reaction in real time) was performed on the apparatus IQ (BioRad) for detection of matrix gene of influenza $A$ and influenza B. The samples positive to influenza A were subtyped by the same method, by RT-PCR, with a specific set of primers for highly conserved regions of X1, X3 and X1 pdm (pandemic).

The data were statistically analyzed with the program SPSS for Windows 13.0, using relevant statistical methodologies. Distribution of frequencies (absolute and relative incidence) was used for qualitative parameters. Descriptive methods such as mean, median and mode were used for mean and typical values of data as well as measures of declination, standard deviation and standard error. For testing the significance of the difference between certain analyzed factors para- 
metric tests (t-test for independent samples, Analysis of Variance) were also used non-parametric tests for independent samples (Mann-Whitney U test, Chi-square test, Fisher-exact test).

Regarding the determination of the prognostic factors of death in patients with influenza the method of multivariate analysis was used (Logistic Binary Regression), by which the relation of probability of exposure (OR) was determined as an approximate value of the real risk (RR). The statistical precision of (OR) was obtained by calculation of the confidence intervals (CI) about the estimated values.

The value of $\mathrm{p}<0.05$ was considered to be statistically significant, and the value of $\mathrm{p}<0.01$ highly significant.

\section{Results}

The study included 87 patients with a severe form of clinically and laboratory confir- med influenza, who were treated at the Clinic for Infectious Diseases and Febrile Conditions in the period from 01.01.2012 to 01.01.2015. Twelve (13.79\%) of them died.

Our results showed that women died insignificantly more often than men $(16.13 \%$ vs $12.5 \%(\mathrm{p}=0.64)$.

The age had significant influence on the disease outcome $(p=0.019)$. The mean age of the deceased patients was $65.58 \pm 17.5$ years, opposite the mean age of the survived patients which was $53.04 \pm 16.8$ years.

The place of living of the patients had no significant influence on the outcome $(p=0.44)$, that is, patients from the rural environment died insignificantly more often than patients from the urban environment ( $22.22 \%$ vs $12.82 \%)$ (Table 1).

Table 1

Demographic characteristics of patients regarding outcome

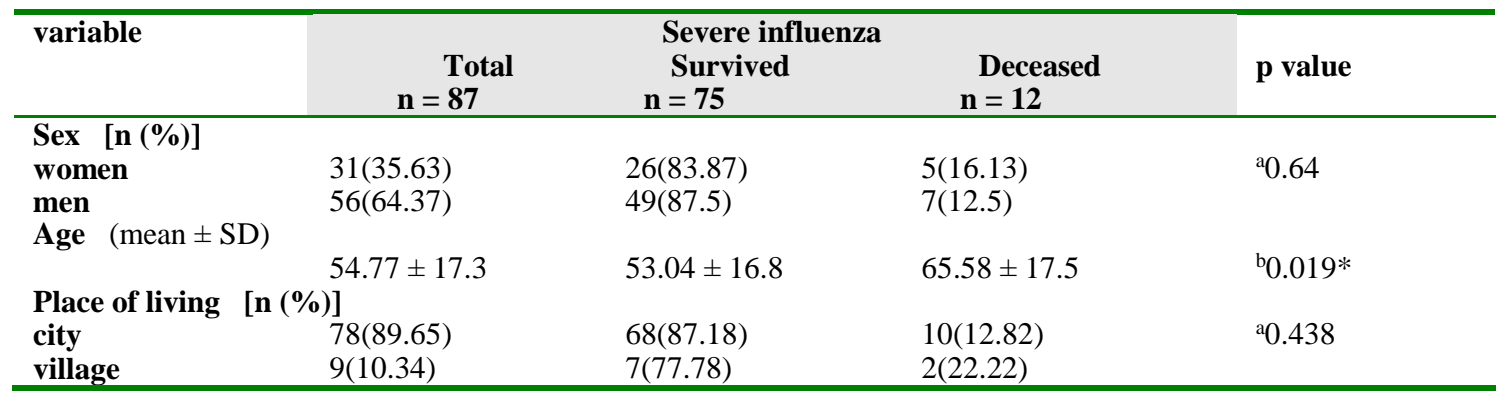

${ }^{\mathrm{a}} \mathrm{p}$ (Chi-square test) ${ }^{\mathrm{b}} \mathrm{p}$ (Student's t- test) ' ${ }^{\mathrm{c}}$ (Fisher exact test) ${ }^{*} \mathrm{p}<0.05$

The patient who was vaccinated against influenza overcame the disease whereas $13.95 \%$ of the patients who were not vaccinated died. $(\mathrm{p}=1.0)$.

Prior to hospitalization $77.78 \%$ of survived patients $22.22 \%$ of patients who died were treated with osaltamivir $(\mathrm{p}=0.6)$. The duration of health problems prior to hospitalization differed significantly between the survived and deceased patients $(p=0.05)$. The mean duration of symptoms prior to hospitalization was 5 days in the group of survived patients and 7 days in the group of deceased patients (Table 2).

Table 2

Vaccination, use of osaltamivir, days prior to admission in relation to outcome

\begin{tabular}{|c|c|c|c|c|}
\hline variable & $\begin{array}{l}\text { Total } \\
\mathbf{n}=\mathbf{8 7}\end{array}$ & $\begin{array}{l}\text { Influenza } \\
\text { Survived } \\
\mathbf{n}=75\end{array}$ & $\begin{array}{l}\text { Deceased } \\
n=12\end{array}$ & p value \\
\hline \multicolumn{4}{|c|}{ Vaccine [n (\%)] } & ${ }^{c} 1.0$ \\
\hline & $86(98.85)$ & $74(86.05)$ & $12(13.95)$ & \\
\hline \multicolumn{5}{|c|}{ Use of osaltamivir prior to admission [n (\%)] } \\
\hline no & $78(89.65)$ & $68(87.18)$ & $10(12.82)$ & ${ }^{\mathrm{c}} 0.6$ \\
\hline yes & $9(10.34)$ & $7(77.78)$ & $2(22.22)$ & \\
\hline \multicolumn{5}{|c|}{ Days prior to admission (median IQR) } \\
\hline & $5(3-7)$ & $5(2-7)$ & $7(4-7)$ & d 0.05 \\
\hline
\end{tabular}

${ }^{\mathrm{a} p}$ (Chi-square test) ${ }^{\mathrm{c}}$ (Fisher exact test) ${ }^{\mathrm{d}}$ (Mann-Whitney U test) 
The highest mortality rate of influenza was registered at the Intensive Care Unit (22.5\%) (p $<0.001$ ). Statistically significant difference was also registered in the outcome of patients who were and who were not treated with mechanical ventilation where significantly dominated the deceased patients who underwent mechanical ventilation $(41.67 \%$ vs $9.33 \% \mathrm{p}=0.01)$ The results of our study have demonstrated that patients with comorbid conditions died more often than those without these diseases $(15.38 \%$ vs $9.09 \%)(p=0.72)$. The cardiovascular diseases had a significant impact on the outcome of influenza $(p=0.011)$. All other analyzed comorbid conditions such as: chronic pulmonary di- seases (survived 92.31\% vs deceased $7.69 \%$ ) $(p=0.68)$, neurological diseases ( $80 \%$ vs $20 \%)$ $(\mathrm{p}=0.62)$, renal diseases $(60 \%$ vs $40 \%)(\mathrm{p}=$ $0.14)$, endocrinological diseases $(88.24 \%$ vs $11.76 \%)(\mathrm{p}=1.0)$, hematological diseases $(83.33 \%$ vs $16.67 \%)(p=1.0)$ were insignificantly associated with outcome in patients with influenza. Small number of patients who had previous immunological disease (1), hepatic diseases (1) and obesity (2) survived in spite of being presented with severe form of influenza. Two pregnant patients also survived. SAPS 2 score which was calculated in the first 24 hours of admission, was significantly associated with lethal outcome (Table 3).

Table 3

Stay at the Intensive care unit, days on intensive care and mechanical ventilation, comorbid conditions, SAPS 2 score in relation to outcome

\begin{tabular}{|c|c|c|c|c|}
\hline variable & $\begin{array}{l}\text { Total } \\
\mathrm{n}=122\end{array}$ & $\begin{array}{l}\text { Influenza } \\
\text { Survived } \\
\mathbf{n}=75\end{array}$ & $\begin{array}{l}\text { Deceased } \\
\mathrm{n}=12\end{array}$ & p value \\
\hline \multicolumn{5}{|c|}{ Intensive [n (\%)] } \\
\hline no & $47(54.02)$ & 46(97.87) & $1(2.13)$ & ${ }^{\mathrm{a}} 0.0006$ \\
\hline yes & $40(45.98)$ & $29(72.5)$ & $11(27.5)$ & \\
\hline \multicolumn{5}{|c|}{ Days at intensive (median IQR) } \\
\hline & $7(3-11)$ & $6(3-10)$ & $8(2-12)$ & ${ }^{\mathrm{d}} 0.72$ \\
\hline \multicolumn{5}{|c|}{ Mechanical ventilation [n (\%)] } \\
\hline no & $75(86.21)$ & 68(90.67) & $7(9.33)$ & ${ }^{\mathrm{c}} 0.01$ \\
\hline yes & 12(13.79) & $7(58.33)$ & $5(41.67)$ & \\
\hline \multicolumn{5}{|c|}{ Comorbid conditions [n (\%)] } \\
\hline no & $22(25.29)$ & 20(90.91) & $2(9.09)$ & ${ }^{\mathrm{c}} 0.72$ \\
\hline yes & $65(74.71)$ & $55(84.62)$ & $10(15.38)$ & \\
\hline \multicolumn{5}{|c|}{ Cardiovascular disease [n (\%)] } \\
\hline no & $44(50.57)$ & 42(95.45) & $2(4.55)$ & ${ }^{\mathrm{a}} 0.011$ \\
\hline yes & 43(49.42) & $33(76.74)$ & $10(23.26)$ & \\
\hline \multicolumn{5}{|c|}{ SAPS 2 score (mean \pm SD) median (IQR) } \\
\hline & $\begin{array}{l}36.4 \pm 29.1 \\
\text { med } 26(17-42)\end{array}$ & $\begin{array}{l}33.7 \pm 28.9 \\
\text { med } 23(16-37)\end{array}$ & $\begin{array}{l}53.4 \pm 24.9 \\
\text { med } 46.5(40-53)\end{array}$ & d $0.00038 * *$ \\
\hline
\end{tabular}

${ }^{a} p$ (Chi-square test) ${ }^{c}$ (Fisher exact test) ${ }^{d}$ (Mann-Whitney U test)

Out of all the laboratory-biochemical analyses conducted on admission, only urea $>8,3$ $\mathrm{mmo} / \mathrm{l}$, showed significant association with a lethal outcome (survived $25.33 \%$ vs deceased $66.67 \%)(\mathrm{p}=0.007)$.

Tables 4 and 4a present the results from Univariate Logistic Regression analysis in determining the analyzed demographic, clinical and biochemical variables that have confirmed to be predictors of the lethal outcome.

The results of the multivariate analysis as independent predictors of lethal outcome, from the analyzed demographic, clinical and biochemical parameters have confirmed the following: cardiovascular comorbidities $(\mathrm{p}=0.014)$, urea values higher than $8.3 \mathrm{U} / \mathrm{L}(\mathrm{p}=0.045)$ and SAPS 2 score (simplified acute physiology score) $(\mathrm{p}=0.048)$.

Patients with influenza and cardiovascular diseases had 2.024 times higher risk of death by influenza when compared to patients with influenza without history of cardiovascular comorbidity (OR $=2.024$ 95\% CI 1.84217.337). 
Table 4

Univariate Logistic regression analysis for prediction of lethal outcome in patients with influenza

\begin{tabular}{lll}
\hline variable & $\begin{array}{l}\text { Crude OR } \\
\mathbf{9 5 \%} \text { CI for OR }\end{array}$ & p value \\
\hline Demographic variables & $1.05(1.006-1.095)$ & $0.025^{*}$ \\
age & $0,743(0.214-2.573)$ & 0.639 \\
Men vs women & $1.943(0.353-10.698)$ & 0.445 \\
Village vs town & $0.515(0.093-2.834)$ & 0.445 \\
Tamiflu prior to admission & $1.818(0.366-9.025)$ & 0.465 \\
Comorbidity & $3.167(0.903-11.102)$ & 0.072 \\
Number of comorbidities & $6.364(1.304-31.055)$ & $0.022^{* *}$ \\
cardiovascular & & \\
Clinical variables (symptoms) & $0.364(0.105-1.259)$ & 0.11 \\
temperature $>37.8^{\circ}$ & $1.067(0.292-3.859)$ & 0.928 \\
dyspnea & $1.056(0.258-4.324)$ & 0.94 \\
cyanosis & $1.109(0.303-4.057)$ & 0.876 \\
Chest pain & $1.313(0.149-11.555)$ & 0.806 \\
pulse $>80$ & $0.8(0.076-8.474)$ & 0.853 \\
SAP <120 & $1.077(0.112-10.369)$ & 0.949 \\
SAP $>120$ & $1.25(0.247-6.318)$ & 0.787 \\
respirations $>20$ & $1.15(1.07-3.18)$ & $0.039 *$ \\
SAPS & $1.091(0.268-4.438)$ & 0.903 \\
RTG finding & & \\
consolidation & & \\
\hline
\end{tabular}

Table 4a

Univariate Logostic regression analysis for prediction of lethal outcome in patients with influenza

\begin{tabular}{lll}
\hline variable & $\begin{array}{l}\text { Crude OR } \\
\text { 95\% CI for OR }\end{array}$ & p value \\
\hline Biochemical variables & & \\
leukocytes $>9$ & $1.027(0.304-3.474)$ & 0.966 \\
thrombocytes $<140$ & $2.0(0.492-8.129)$ & 0.333 \\
thrombocytes $>250$ & $0.737(0.136-3.992)$ & 0.723 \\
glycemia $>6.3$ & $1.891(0.473-7.569)$ & 0.368 \\
urea $>8.3$ & $5.89(1.593-21.807)$ & $0.008 * *$ \\
creatinine $>110$ & $2.222(0.627-7.87)$ & 0.216 \\
potassium $<3.5$ & $0.429(0.05-3.672)$ & 0.492 \\
potassium $>5.5$ & $1.714(0.306-9.599)$ & 0.54 \\
sodium $<135$ & $0.653(0.126-3.372)$ & 0.611 \\
sodium $>145$ & $1.175(0.216-6.388)$ & 0.852 \\
ALT $>52$ & $1.706(0.457-6.362)$ & 0.426 \\
AST $>47$ & $1.885(0.552-6.431)$ & 0.312 \\
LDH $>618$ & $3.152(0.644-15.422)$ & 0.156 \\
CPK $>170$ & $1.083(0.32-3.655)$ & 0.898 \\
bilirubin $>17$ & $1.05(0.204-5.407)$ & 0.953 \\
bicarbonates & $1.893(0.583-6.653)$ & 0.32 \\
\hline
\end{tabular}

Patients with serum urea levels higher than $8.3 \mathrm{U} / \mathrm{L}$ had 1.89 times greater chance for dying compared to patients with normal values (OR = 1.89 95\% CI 1.091-11.432).
The increase of SAPS score for one score increases the chance of death in patients with influenza by $1.2 \%(\mathrm{OR}=1.12$ 95\% CI $1.01-$ 2.976). 
Table 5

Multivariate Logistic regression analysis for prediction of lethal outcome in patients with influenza

\begin{tabular}{lll}
\hline variable & $\begin{array}{l}\text { Adjusted OR } \\
\text { 95\% CI for OR }\end{array}$ & p value \\
\hline Cardiovascular & $2.024(1.842-17.337)$ & $0.014^{*}$ \\
urea > 8.3 & $1.89(1.091-11.432)$ & $0.045^{*}$ \\
SAPS score & $1.12(1.01-2.976)$ & $0.048^{*}$ \\
\hline
\end{tabular}

ROC analysis has demonstrated that the combination of cardiovascular diseases, the increased urea values and the SAPS score are a good prognostic model of the lethal outcome. The area under the ROC curve, that is, AUC was 0.755 , with $95 \%$ confidence interval from
0.587-0.923 suggesting that the probability of combination of these two predictors for death in influenza patients was $75.5 \%$.

The global precision of this predictive model to foresee the lethal outcome was $80 \%$, sensitivity $82 \%$, and specificity $70 \%$.

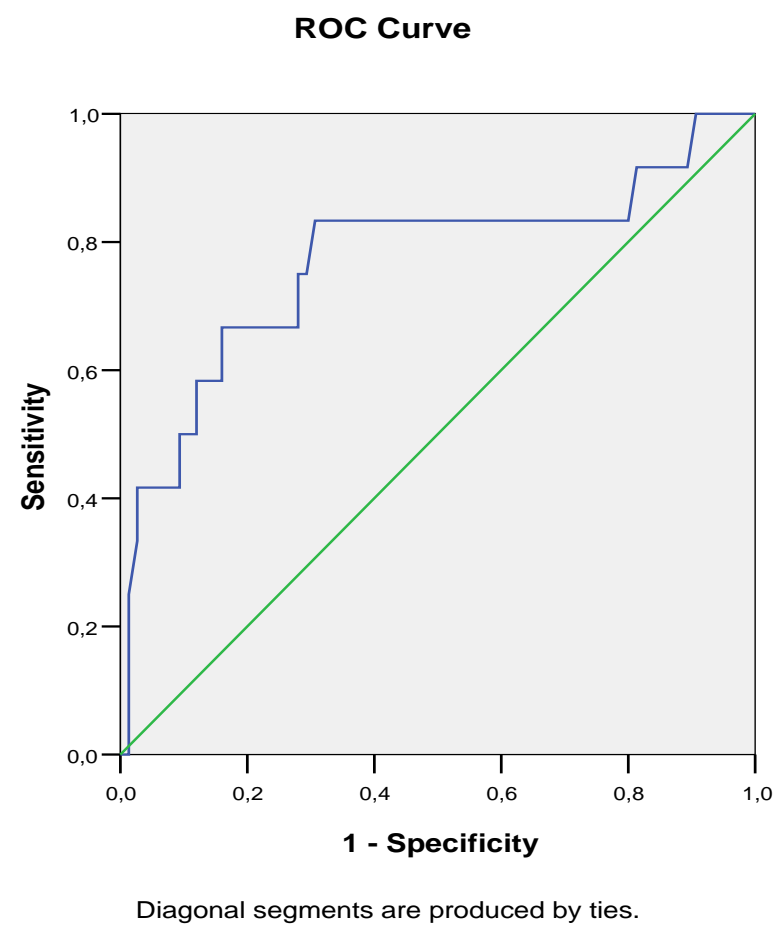

Figure 1 - ROC curve for the influence of cardiovascular diseases, urea and SAPS score in prediction of lethal outcome from influenza

\section{Discussion}

The mortality rate of the hospitalized patients with severe influenza infection amounted to $13.79 \%$ in our study. The percentage of lethality varies among published studies and it ranges from $10 \%$ to extreme $59 \%$, which certainly depends on the various conditions and criteria according to which the patients are analyzed as well as on the criteria for admission to intensive care units [13-15]. Thus, the study performed in China showed that from 60 patients with severe form of influenza $44 \%$ were treated at Intensive care unit and the lethality was $14.7 \%$ [16].

There was no a significant difference regarding the mortality between male and female patients in our study, although in most of the studies the male sex was identified as a risk factor associated with lethal outcome. [17, 18]. Our results have demonstrated that from the total number of 12 lethal outcomes 5 or (16.1\%) were women and 7 (12.5\%) were men. Our study is similar to that conducted in Canada where from the total number of 29 lethal out- 
comes, $27.6 \%$ were men, whereas $72.4 \%$ were women [17]. The age had significant influence on the disease outcome in our study. The mean age of patients that died was $65.58(\mathrm{p}=0.019)$. The mortality was the highest in patients at the age over $65(27.2 \%)$. These results coincide with almost all studies in the world that identify the old age as an important risk factor for mortality in patients with influenza [19]. The place of living of the patients was not significant in relation to the outcome. Patients from the rural environment exited as patients from the urban environment, $22.2 \%$ vs $12.8 \%$.

According to many studies the use of neuraminidase inhibitor within 48 hours from the beginning of the symptoms decreases the risk of progression into a severe form and death of patients with influenza. In addition, the guidelines of the WHO recommend early treatment with oseltamivir for suspected influenza cases and warn that delayed medical attention increases the mortality rate [20]. In our study, 89.6\% of patients did not use osaltamivir prior to admission, whereas only $10.35 \%$ of them used this medication. In the first group the mortality rate was $12.8 \%$ vs $22.2 \%$ in the second group $(p=0.06)$. The answer probably lies in two important issues. The first one is the small group of patients and the second one arises from the existence of resistant forms of the virus [21, 22].

The results of our study have shown that in the group of patients with severe influenza without comorbidity the mortality rate was 9.09\% whereas in the group of patients with associated comorbid diseases the mortality rate was higher than in the first one (15.38\%) ( $p=$ 0.72 ). The analysis of identified associated chronic conditions have shown that cardiovascular diseases had significant influence on the outcome from influenza $(\mathrm{p}=0.011)$. While patients with a negative history of cardiovascular comorbidity yielded a mortality rate of $4.55 \%$, the patients who did have cardiovascular disease present, yielded a significantly higher mortality rate of $23.26 \%$ [5].

All 87 patients with severe influenza in our study had higher body temperature than $37.8^{\circ}$. The mean body temperature between the group of survived and deceased patients showed no statistically significant correlation $(38.7 \pm 0.7$ vs $38.4+0.8) \mathrm{p}=\mathrm{ns}$. The other clinical symp- toms that were analyzed did not differ among themselves in the group of survived patients and those that died, although the latter group complained on cough, dizziness, dyspnea and chest pain [23-25].

In all of the patients where the diagnostic protocol included chest radiologic procedures in our study, the statistical analysis indicated that $60 \%$ of patients that had diffuse bilateral consolidation died contrary to $10.9 \%$ of patients who did not have this type of radiologic finding $(\mathrm{p}=0.017)$ [26].

Laboratory and biochemical analyses were performed in patients on their admission to the Clinic, 24 and 48 hours after admission. The statistical analysis showed significantly decreesed values of erythrocyte the second day of the hospitalization ( $p=0.009$ ), higher mean value of sedimentation rate $(p=0.02)$ as well as higher percentage of neutrophils in the group of deceased patients opposite to the survived patients $(p=0.0005)$. In relation to the remaining biochemical parameters the glycemia was with higher values in the group of deceased patients but statistical significance was confirmed only 48 hours after admission ( $p=0.001)$. In all three measurements the level of urea higher than 8.3 $\mathrm{mmol} / \mathrm{l}$ was significantly more often in the group of deceased patients $(\mathrm{p}=0.007, \mathrm{p}=0.0027$ and $\mathrm{p}=0.017)$.

The creatinine level higher than 110 micromol/l demonstrated statistically significant difference between the two groups only in the period of 24 hours after hospitalization. These findings correlate with most of the studies where the increased level of serum createnine was confirmed as a significant statistical factor that had influence on the outcome.

With reference to the mean values of bilirubin, CRP, ALAT, ASAT, CPK, LDH albumins and total proteins analyzed on admission, 24 and 48 hours after admission, the following parameters were statistically significant in the group of patients who died: bilirubin 48 hours after admission ( $p=0.038)$, CRP after 24 and 48 hours $(p=0.01), p=0.0004)$, ASAT after 24 hours $(p=0.006)$ albumins after 48 hours ( $p$ $=0.019$ ) and total proteins on admission, 24 and 48 hours $(\mathrm{p}=0.007, \mathrm{p}=0.002$ and $\mathrm{p}=$ $0,002)$. All these results are in agreement with 
a large number of studies that have analyzed the lab-biochemistry parameters $[14,18,19]$.

As independent predictors for lethal outcome in patients with influenza, we have identified the following variables: cardiovascular diseases $(p=0.014)$, urea levels higher than 8.3 $(p=0.045)$ and SAPS score $(p=0.048)$. Patients with influenza and cardiovascular diseases had 2.024 times higher risk of death of influenza compared to influenza patients without history of cardiovascular comorbidity. The confidence interval was $98 \%$. Those patients that had urea levels higher than 8.3 had 1.89 times bigger chance for lethal outcome compared to patients with normal values of urea. The increase of SAPS score for one score raises the risk of death in patients with influenza by $1.2 \%$.

\section{Conclusion}

In our study the mortality rate was 13.9\%. Cardiovascular diseases, the increased urea level over $8.3 \mathrm{mmol} / \mathrm{l}$ and SAPS score have been identified as independent variables, which have predicted the outcome in patients with severe influenza on the very admission to the Clinic demonstrating precision of this predictive model of $80 \%$.

The early identification of the outcome predictors in patients with severe influenza will ensure implementation of adequate medical procedures, and also, it will contribute to decreasing the mortality of this disease.

\section{REFERENCES}

1. Thompson WW, Moore MR, Weintraub E Cheng PY, Jin $X$, Bridges CB, Bresee JSS, Shay DK. Estimating Influenza-Associated Deaths in the United State Am J Public Health. 2009; 99(2):225-230.

2. Young SJ, Hee JC, Heung JW, Seong-Heon W, JinSoo L, Moon-Hyun C, et al. Immunogenicity and Safety of Trivalent Inactivated Influenza Vaccine: A Randomized, Double-Blind, Multi-Center, Phase 3 Clinical Trial in a Vaccine-Limited Country. J Korean Med Sci. 2011; 26(2): 191-195

3. Zimmerman O, Rogowski O, Aviram G, Mizrahi M, Zeltser D. Justo D, et al. C-reactive protein serum levels as an early predictor of outcome in patients with pandemic H1N1 influenza A virus infection. BMC Infectious Diseases 2010, 10: 288

4. Blyth CC, Iredell JR, Dwyer DE. Rapid-test sensitivity for novel swine-origin influenza A (H1N1) virus in humans. N Engl J Med. 2009; 361(25): 2493.
5. Kalyani1 D, Srikanth Bhatt S, Chitralekha T, Rajarao M, Shankar K. Comorbidities In H1N1 Positive Patients - Hospital Based Study, IOSR Journal of Dental and Medical Sciences. 2016;15:52-55.

6. Oh WS, Lee SJ, Lee CS, Hur JA, Hur AC, Park YS, et al. A prediction rule to identify severe cases among adult patients hospitalized with pandemicinfluenza A H1N1)2009. J Korean Med Sci.2011 Apr; 26(4): 499-506.

7. Mata-Marín LA, Mata-Marín JA, Vásquez-Mota VC, $\mathrm{Ar}-$ royo-Anduiza CI, Gaytán-Martínez JE, Manjarrez-Téllez $\mathrm{B}$, et al. Risk factors associated with mortality in patients infected with influenza A/H1N1 in Mexico.BMC Res Notes. 2015 Sep 11; 8: 432.

8. Woo HC, Yun SK, Doo SJ, Ji EK, Kun IK, Hee YS, et al. Outcome of pandemic H1N1 pneumonia: clinical and radiological findings for severity assessment. Korean J Intern Med. 2011; 26: 160-167.

9. Liu L, Zhang RF, Lu HZ, Lu SH, Huang Q, Xiong YY, Xi XH, Zhang ZY. Sixty-two severe and critical patients with 2009 influenza A (H1N1) in Shanghai, China.Chin Med J (Engl).2011 Jun; 124(11): 1662-6.

10. Yokota RT, Skalinski LM, Igansi CN, de Souza LR, Iser BP, Reis PO, et al. Risk factors for death from pandemic (H1N1) 2009, southern Brazil.Emerg Infect Dis. 2011 Aug; 17(8): 1467-71.

11. LLi| G, Yilmaz M, Kojicic M, Fernández-Pérez E, Wahab R, Charles Huskins W, et al. Outcome of critically ill patients with influenza virus infection. Journal of Clinical Virology. 2009;46 (3): 275-278,

12. Thompson WW, Shay DK, Weintraub E, et al. Influenza-associated hospitalizations in the United States. JAMA. 2004; 292: 1333-1340.

13. Louie JK, Acosta M, Winter K, Jean C, Gavali S, Schechter R, et al. California Pandemic (H1N1) Working Group. Factors associated with death or hospitalization due to pandemic 2009 influenza A(H1N1) infection in California. JAMA. 2009; 302(17): 1896902. doi: 10.1001/jama.2009.1583.

14. BinSaeed AA. Characteristics of pandemic influenza A (H1N1) infection in patients presenting to a university hospital in Riyadh, Saudi Arabia. Ann Saudi Med. 2010; 30(1): 59-62.

15. Domínguez-Cherit G, Lapinsky SE, Macias AE, Pinto R, Espinosa-Perez L, de la Torre A, et al. Critically Ill patients with 2009 influenza A(H1N1) in Mexico. JAMA. 2009; 302(17): 1880-7. doi: 10.1001/jama.2009.1536. Epub 2009 Oct.

16. Cui W, Zhao H, Lu X, Wen Y, Zhou Y,Deng B, et al. Factors associated with death in hospitalized pneumonia patients with 2009 H1N1 influenza in Shenyang, China. BMC Infect Dis. 2010May 31; 10: 145.

17. Kumar A, Zarychanski R, Pinto R, Cook D, Marshall J, Lacroix J, et al. Critically ill patients with 2009 influenza A (H1N1) infection in Canada. JAMA. 2009; 302: 1872-9.

18. Cao B, Li XW, Mao Y, Wang J, Lu HZ, Chen YS, et al. Clinical features of the initial cases of 2009 pandemic influenza A (H1N1) virus infection in China. N Engl J Med. 2009; 361: 2507-17.

19. Chen KF, Gaydos C, Rothman RE. Update on emerging infections: news from the Centers for Disease Control and Prevention. Hospitalized patients with novel influenza A (H1N1) virus infection-Califor- 
nia, April-May, 2009. Ann Emerg Med. 2009; 54(5): 732-6.

20. Cheng VCC, To KKW, Tse H, Hung IFN, Yuen KY. Two years after pandemic influenza A/2009/H1N1: what have we learned? Clin Microbiol Rev.2012; 25: 223-63.

21. Moa AM, Chughtai AA, Muscatello DJ, Turner RM, MacIntyre CR. Immunogenicity and safety of inactivated quadrivalent influenza vaccine in adults: A systematic review and meta-analysis of randomised controlled trials.Waccine. 2016 Jul 2. pii: S0264410X(16)30515-1.

22. Sridhar S, Brokstad KA, Cox RJ, et al. Influenza vaccination strategies: comparing inactivated and live attenuated influenza vaccines. Vaccines. 2015; 3: 373389.

23. Loubet P, Samih-Lenzi N, Galtier F, Vanhems P, Loulergue $\mathrm{P}$, Duval $\mathrm{X}$, et al. Factors associated with poor outcomes among adults hospitalized for influenza in France: A three-year prospective multicenter study.J Clin Virol.2016 Jun; 79: 68-73.

24. Herrmannová K, Trojánek M, Havlíčková M, Jiřincová $\mathrm{H}$, Nagy A, Blechová Z, et al. Clinical and epidemiological characteristics of patients hospitalized with severe influenza in the season 2012-2013. Epidemiol Mikrobiol Imunol.2014 Feb; 63(1): 4-9.

25. Leung $\mathrm{CH}$, Tseng HK, Wang WS, Chiang HT, Wu AY, Liu CP. Clinical characteristics of children and adults hospitalized for influenza virus infection. $\mathrm{Mi}$ crobiol Immunol Infect. 2014 Dec; 47(6): 518-25.

26. Viasus D, Marinescu C, Villoslada A, Cordero E, Gálvez-Acebal J, et al.CarratalàJ. Community-acquired pneumonia during the first post-pandemic influenza season: a prospective, multicentre cohort study. J Infect. 2013 Sep; 67(3): 185-93.

\section{Резиме}

\section{ФАКТОРИ АСОЦИРАНИ СО СМРТЕН ИСХОД КАЈ ПАЦИЕНТИ СО ТЕШКА ФОРМА НА ИНФЛУЕНЦА}

\section{Марија Цветановска ${ }^{1}$, Звонко Миленковиќ ${ }^{1}$, Валерија Кирова-Урошевиќ', Илир Демири ${ }^{1}$, Влатко Цветановски ${ }^{2}$}

\footnotetext{
${ }^{1}$ Клиника за инфективни болести и фебрилни состојби, Клинички центар, Скопје,

Р. Македонија

2 Општа болница „Ремедика“, Скопје,

Р. Македонија
}

Вовед: Клиничките манифестации на инфлуенца се движат во дијапазон од релативно лесни и самолимитирачки респираторни инфекции до тешки клинички манифестации со сигнификантен морбидитет и морталитет. Познавањето на предикторите за смртен исход од инфлу- енца е од посебно значење за донесување навремена и правилна одлука за соодветен третман.

Цел на оваа студија е да се идентификуваат факторите кои укажуваат на смртен исход кај пациентите со тешка форма на инфлуенца.

Материјал и методи: Истражувањето е проспективно групно споредбено и е изведено на Универзитетската клиника за инфективни болести во Скопје, Р. Македонија, во период од 1 јануари 2012 до 1 јануари 2015 година. Во студијата се вклучени возрасни пациенти со тешка форма на инфлуенца кои понатаму се поделени на група преживеани и група починати пациенти. При вклучување во студијата се бележени демографски, клинички и биохемиски податоци. Варијаблите од униваријантната анализа кои покажаа значајна разлика во однос на исходот се употребени за изработка на мултиваријантна логистичка регресивна анализа за исходот како зависни фактори. Со логистичката регресија се добиени независни предиктори за смртен исход од тешка форма на сезонска инфлуенца.

Резултати: Во студијата беа вклучени 87 пациенти со тешка форма на клинички и лабораториски потврдена сезонска инфлуенца. Болните беа поделени во две групи: преживеани $($ н $=75)$ и починати $($ н = 12). Вкупната смртност изнесуваше $13,79 \%$. Мултиваријантната анализа при приемот ги издвои кардиолошките коморбидитетни болести $(\Pi=0,014)$, вредностите на уреа повисоки од 8,3 У/Л $(п=0,045)$ и САПС скорот $(\Pi=0,048)$ како независни показатели кои го предвидуваат исходот кај болните со тешка инфлуенца. Пациентите со инфлуенца и кардиолошки заболувања имаат за 2,024 пати поголема шанса за смрт од инфлуенца, компарирано со пациентите со инфлуенца без историја за кардиолошки коморбидитет $(\mathrm{OR}=2,024$ 95\% CI 1,842 - 17.337). Пациентите со вредности на уреа во серум повисоки од $8,3 \mathrm{U} / \mathrm{L}$ имаа за 1.89 пати поголема шанса за егзитирање, компарирано со пациентите со нормални вредности $(\mathrm{OR}=1,89$ 95\% CI 1.091 - 11,432). Зголемувањето на САПС-скорот за еден скор ја зголемува шансата за смрт кај пациентите со инфлуенца за 1,2\% (OR = 1,12 95\% CI 1.01 - 2,976).

ROC-анализата покажа дека кардиолошките заболувања, покачени вредности на уреа и САПС скорот како комбинација претставуваат сигурен прогностички модел за летален исход. Глобалната точност на овој предиктивен модел да предвиди летален исход изнесува $80 \%$, сензитивноста е $82 \%$, специфичноста е $70 \%$.

Заклучок: Кардиолошките заболувања, покачените вредности на уреа над 8,3 ммол/л и 
САПС-скорот се независни предиктори за смртен исход кај тешка инфлуенца. Раната идентификација на показателите на исходот кај болните со тешка инфлуенца ќе овозможи имплементација на адекватни медицински постапки и ќе придонесе за намалување на морталитетот на болните со тешка форма на сезонска инфлуенца.

Клучни зборови: тешка инфлуенца, предиктори, смртен исход 